Archives of Agriculture and Environmental Science

\title{
Impact of forest land cover on runoff, erosion and sedimentation in the Karai Watershed, Simalungun Regency, North Sumatra Province, Indonesia
}

\author{
Basuki Wasis $^{1^{*}}$ (D) , Dhemi Harlan² and Muhammad Hafiz Wasis Putra ${ }^{3}$ \\ ${ }^{1}$ Department of Silviculture, Faculty of Forestry, IPB University. Bogor, West Java, INDONESIA \\ ${ }^{2}$ Faculty of Civil and Environmental Engineering, Bandung Institute of Technology, Bandung, West Java, INDONESIA \\ ${ }^{3}$ Alumni, Department of Environment Economic, Faculty of Management and Economic, IPB University. Bogor, West Java, \\ INDONESIA \\ *Corresponding author's E-mail: basuki_wasis@yahoo.com
}

\section{ARTICLE HISTORY}

Received: 17 December 2020

Revised received: 08 March 2020

Accepted: 13 March 2020

\section{Keywords}

Erosion

Forest cover

Karai watershed

Run off

Sedimentation

\begin{abstract}
Development activities in the Karai Watershed, in upstream area, are intensive. The activities tend to decrease the land abilities in absorbing water and protecting surface soil for erosion, which finally affect the rise of vegetation damage, soil damage, surface run-off and erosion The method of taking samples and analyzing environmental damage were conducted by purposive sampling. Data from laboratory tests of soil physical, chemical and biological properties were analyzed by statistical tests. Measurement result shows that the wide of Karai Watershed is $462 \mathrm{~km}^{2}$, in which covered forest wide is $115.5 \mathrm{~km}^{2}$ (25\%) and the wide of non-forest area (garden, dwelling site, road etc) is $346.5 \mathrm{~km}^{2}$ (75\%). Land Cover for non forest area is the biggest sediment source in Karai Watershed. Based on observation on field and laboratory analysis, it shows that conservation activities in natural forest to garden, road, and dwelling site have caused damages to soil (parameter bulk density and total fungi) and environment with indicators of erosion, sediment materials in Karai River and Karai 7 Project location. Observation result shows that program to reduce erosion and sedimentation could be implemented by integrated management program of Karai Watershed with priorities to develop mixed garden and agroforestry.
\end{abstract}

(C)2020 Agriculture and Environmental Science Academy

Citation of this article: Wasis, B., Harlan, D. and Putra, M.H.W. (2020). Impact of forest land cover on runoff, erosion and sedimentation in the Karai Watershed, Simalungun Regency, North Sumatra Province, Indonesia. Archives of Agriculture and Environmental Science, 5(1): 40-49, https://dx.doi.org/10.26832/24566632.2020.050106

\section{INTRODUCTION}

Watershed in Karai river, Simalungun District, is one of catchment areas that flows into Toba Lake, which is in Northern Sumatera Province and has the wide of $462 \mathrm{~km}^{2}$ beginning from 190-225 m elevation to the downstream of Toba Lake. Natural forest vegetation is the best land cover for hydroorological functions. Conversion of natural forests will have an impact on reducing hydroorological functions (Whitmore, 1975; Bapenas, 2003; Wasis, 2012). Development activities in Karai Watershed (Catchment Area), in upstream area, are intensive. The activities tend to decrease the land abilities in absorbing water and protecting surface soil for erosio, which finally affect the rise of surface run-off and erosion (Wasis, 2012 Wasis et al., 2018,
Wasis et al., 2019). Population growth is identified as the cause of water quality decreases in Karai river. With the population growth, road construction, land clearance, and ecology pressure for the river decreases water quality of the river and rises sedimentation (sand). Landslide occurance, sedimentation at Pembangkit Listrik Tenaga Mikrohidro (PLTM) or Micro-hydro Electric Power (Karai 7 and Karai 13), and the decrease of water quality in the river are the evidence of failure indication in managing resources (forest and land resources).

Issues of environment quality decrease in watershed management, especiallly landslide issue, erosion, sedimentation, is a dispute that has to be solved quickly, for this issue has caused faster sedimentation proccess. At PLTM Karai 7, sedimentary trap management is maintained per two days, thus 
this activity decreases the ability of PLTM to produce electricity. Damage Forest (Illegal logging) had a significant effects toward the bulk density increase, as well as C-organic decrease. In other hand Illegal logging had a significant effects on sand fraction,total microorganisms, and soil respiration (Wasis, 2019). Landslide proccess, erosion, sedimentation are caused of the conversion of forest coverage, the change of natural forest converted into garden, dwellings, mine site, and road construction. For that reason, analysis of biophysics condition, analysis of forest coverage, and rehabilitation effort is needed. To solve this environmental problem at this catchment area, it needs to include all stakeholders (local citizen, local companies, and government). Therefore, The plan of Karai Watershed has to be created to increase the integrity among local stakeholders included in the management of catchment area resources by coordinating, integrating, sychronizing some aspects (policies,management activities, and development of effective and efficient catchment area). Based on those management, all stakeholders has some agreements and commitment to construct program and also do some efforts to achieve those purposes that has been agreed together. This study aimed to collect forest coverage data at Karai Catchment Area, to analyse the cause of damaged soil and damaged environment which are the rise of soil sedimentaion at Karai river and to assemble program and activitiy guidance in managing the inrease and rehabilitation of natural resources and land at the Karai Watershed.

\section{MATERIALS AND METHODS}

\section{Research place and time}

These activities will be conducted at the Karai Watershed (PLTM Karai 7 and Karai 13) Kahean Sub-district, Simalungun District, in various types of land coverage (tropical rain forest, agroforestry, local garden, road, damage soil, etc.). This research is conducted at January $16^{\text {th }}$ January $18^{\text {th }} 2017$.

\section{Tools and materials}

Research tools used are differentiated into two categories, which are data collecting tools on site and nutrient analysis tools at laboratories. Data collecting tools on site are complete sample collecting tools (ring sample), to take the composite soil samples by hoe, knife, ruler, plastic bag and marker. The details of those seven locations:

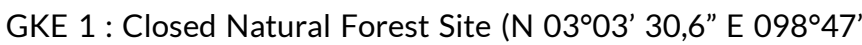
$51,7 ")$

GKE 2 : Cleared land for road construction ( $N 03^{\circ} 03^{\prime} 43,0^{\prime \prime} \mathrm{E}$ $098^{\circ} 47^{\prime}$ 51,9")

GKE 3 : Cleared land for road construction ( $N 03^{\circ} 03^{\prime} 35,7^{\prime \prime} \mathrm{E}$ $\left.098^{\circ} 47^{\prime} 56,2^{\prime \prime}\right)$

GKE 4 : Cleared land for dam construction ( $N 03^{\circ} 02^{\prime}$ 50,4" E $\left.098^{\circ} 47^{\prime} 01,4^{\prime \prime}\right)$

GKE 5 : Cleared land for dam construction( $\mathrm{N} 03^{\circ} 02^{\prime} 44,9^{\prime \prime} \mathrm{E}$ $\left.098^{\circ} 46^{\prime} 54,9^{\prime \prime}\right)$
GKE 6 : Gardening Site (N 0303' 26,3" E 098 48' 01,2”)

GKE 7 : Gardening Site (N 0303' 03,3" E 09848' 27,2”)

\section{Research procedures}

Structure analysis and vegetation ingredient: Monitoring square establishment is choosed by purposive sampling at Karai Catchment Area. To assess the effect of changing land usage for triggered erosion, damaged soil, and damaged plants, sampling on various land (7 locations which each sample is $20 \mathrm{~m} \times 20 \mathrm{~m}$ ) is conducted (Soerianegara dan Indrawan, 2005; Wasis, 2012).

Collecting soil samples: Soil sampling is done by purposive sampling on tropical rain forest, garden and damage soil. The study was conducted on three plots on tropical rain forest and damage forest of $20 \mathrm{~m} \times 20 \mathrm{~m}$ (0.04 ha) each. Within the mine, tropical rain forest and damage forest, three subplots of $1 \mathrm{~m} \times$ $1 \mathrm{~m}$ were placed randomly for ground sampling. Then the soil sample is composited. Soil sampling for the chemical properties and biological properties of soil is taken evenly on the soil surface of $0-20 \mathrm{~cm}$ deep. Soil taking is done by composite as much as $1 \mathrm{~kg}$. Soil sampling for soil physical properties was done at ground level of $0-20 \mathrm{~cm}$ depth (Figure 1). Intake of soil is done intactly by using ring sample diameter of $7 \mathrm{~cm}$ with height of $5 \mathrm{~cm}$ (Wasis, 2012).

Soil analysis: Soil that has been take from the field are the analyzed at Forestry Influence Laboratory, Silviculture Department, Faculty of Forestry IPB. Soil analysis for physics properties are bulk density, porosity, available water, and permeability, for chemistry properties are soil pH and c-organic, and for biology properties is total microorganism, total fungi, and respiration.

\section{Data analysis}

Site monitoring data and soil analysis result are then analyzed based on current related rules (PP No.150, 2000) to know the damage that has been made (PLTM Karai 7). Coefficients for soil properties is bulk density, porosity, available water, permeability, $\mathrm{pH}$, total microorganism, and total fungi.

\section{RESULTS AND DISCUSSION}

The calculated result predicts the broad of The Karai watershed is $462 \mathrm{~km}^{2}$, in which the wide of forest coverage is $115.5 \mathrm{~km}^{2}$ (25\%) and the wide of non-forest coverage (garden, dwelling sites, road, etc.) is $346.5 \mathrm{~km}^{2}$ (75\%). This non-forest land coverage will trigger the increase of landslide, erosion, and runoff. It is proved by the high of sediment trap at PLTM Karai 7. The observation result illustrates that land clearance has caused damaged land by triggering erosion, the lost of soil nutrient and the increase of rock coverage at the soil surfaces. Damage at those things will surely increase sand sedimentation at Karai Watershed (PP No.150, 2000). For more detailed result, it is shown at Table 1. 


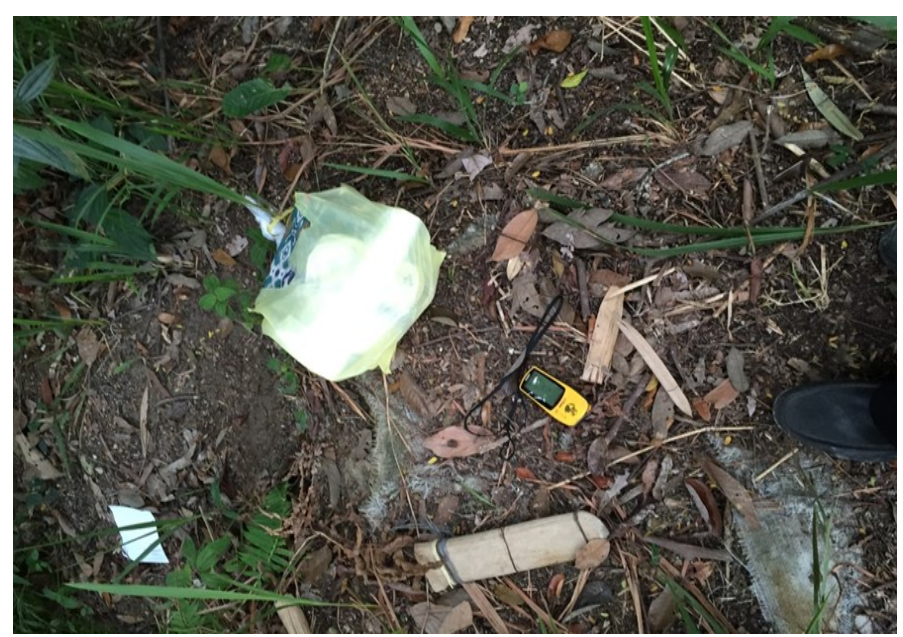

Figure 1. Soil sampling at Karai catchment area.

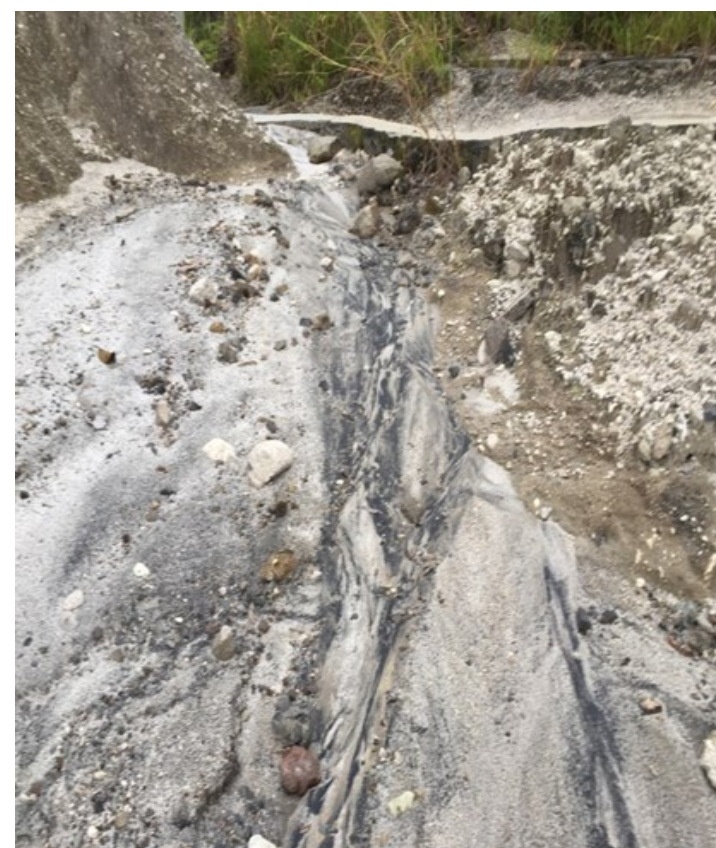

Figure 3. Eroded land at Karai watershed.

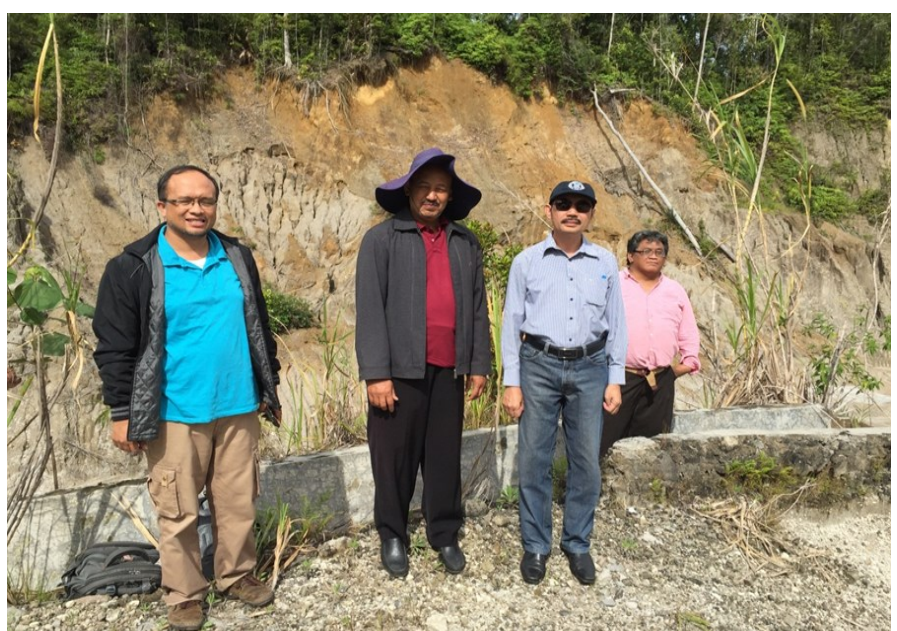

Figure 2. Landslide caused by road construction at Karai watershed.

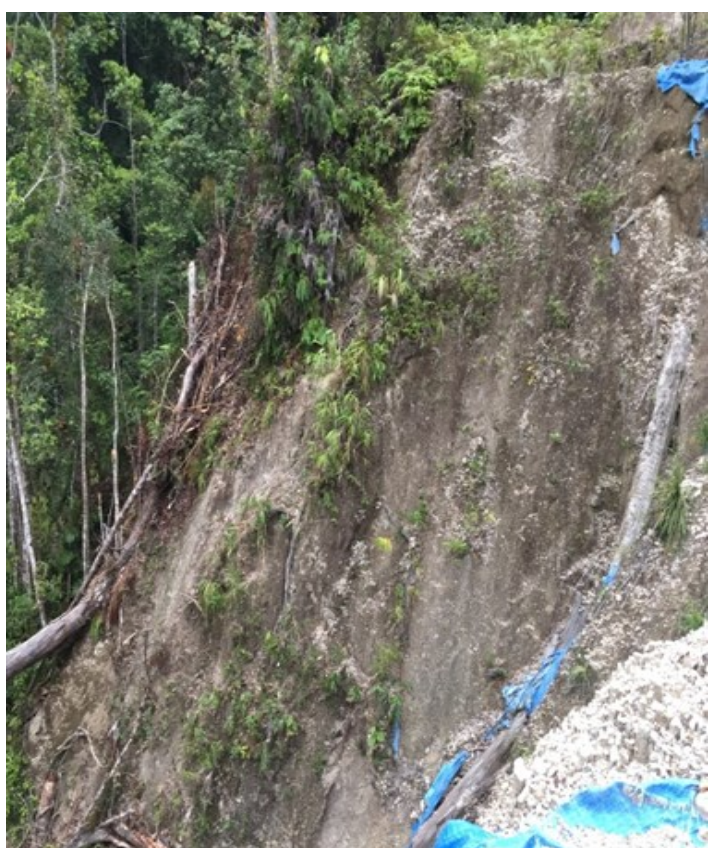

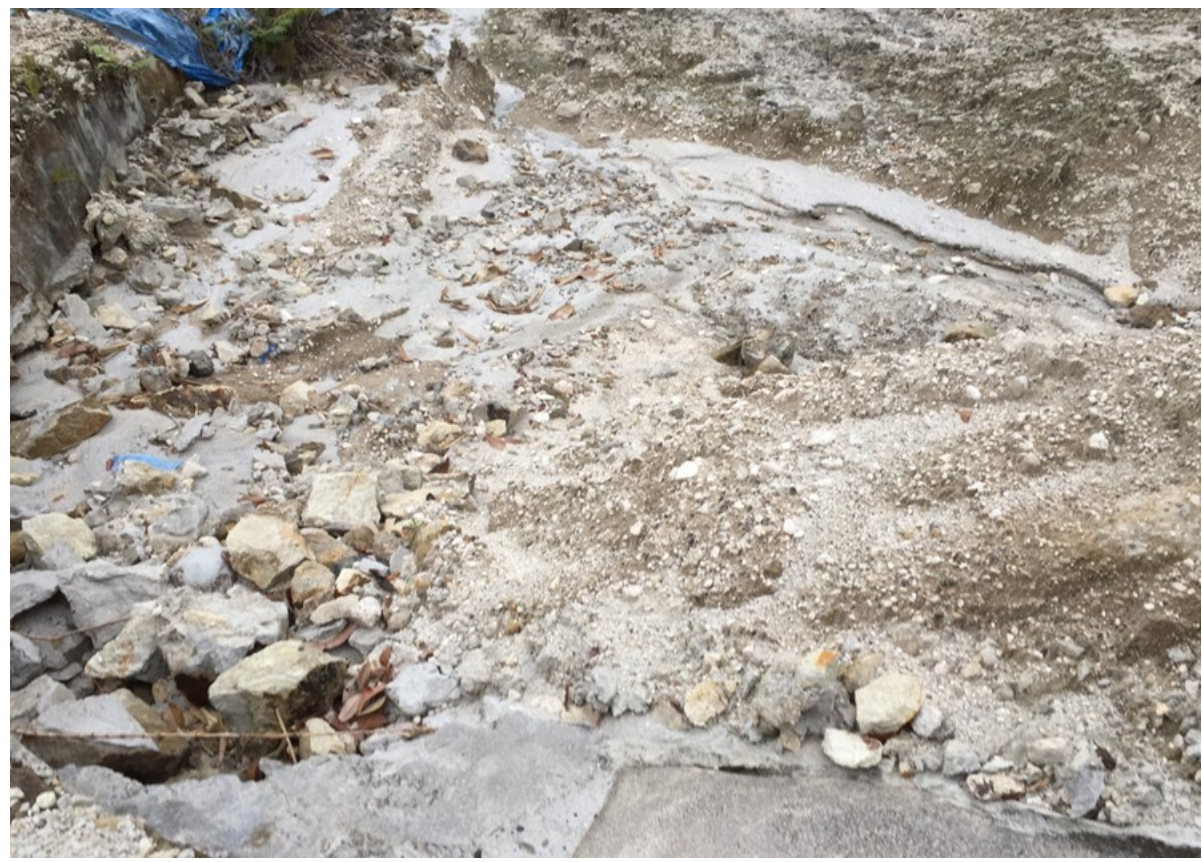

Figure 4. The loss of soil materials at Karai watershed. 
Converting natural forest to gardening site, road and damaged soil

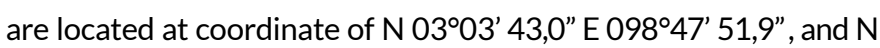
$03^{\circ} 03^{\prime} 35,7^{\prime \prime} \mathrm{E} 098^{\circ} 47^{\prime}$ 56,2", in which cleared podsol land, caused by road construction and soil erosion accounting for $20-150 \mathrm{~cm}, \mathrm{~s}$ found on site. (Figure 2). Most of erosion materials enter Karai riverbank. This occurance has constibuted enormous sediment materials inside the river. On the site, landslide is also found.

\section{Water system of Karai watershed}

Laboratory analysis result shows that land clearing has damaged water system function, which are the decreasing Available water the decreases infiltration. damaage of water sistem will certainly increase sand sedimentation and will decrease water quality in Karai River (PP Number 150, 2000). For further detail, it can be seen in the Tables 2 and 3 .

Other effects of damaged natural forest changing to open land and gardening site are the available water decreases in conservating water. It can be seen in the decrease of available water to infiltrate water, which is indicated by the decrease of permeability accounting for $1.98-8.12 \mathrm{~cm} /$ hour and the decrease of available water amounting to $0.01 \%-43.43 \%$. Those effects tend to run off the water dropped to the ground because of disability of land to absorb in into the soil. Big effects of this occurence will bring soil textures (sand, dust, and clay) into the Karai river. Soil damage caused by logging activities, land clearing and soil proccessing has decreased soil infiltration abality amounting to $564-2.314 \mathrm{~cm} /$ hour. It can be caused by damaged soil structure and the decrease of organic materials on soil surfaces. Soil structure damage will decrease drainage pore. As a result, rain water will mostly fall and become run off. This run off level will tend to increase the level of eroded land in Karai Watershed (Figure 3 and 4).

Soil physical properties

Laboratory analysis result show that land clearing has affected in land physical damage which are the increase of bulk density, and the decrease of soil porosity. The damage of physical soil property will certainly decrease of soil infiltration levels and will increase surface runoff in Karai River (Nomor, 2000). For futher details, it is illustrated in the Tables 4 and 5.

Table 1. Soil damage for natural forest convertion into cleared land.

\begin{tabular}{clcccccc}
\hline S.N. & $\begin{array}{l}\text { Parameter } \\
\text { (PP No 150 Th 2000) }\end{array}$ & GKE 2 & GKE3 & GKE4 & GKE5 & GKE6 & GKE7 \\
\hline 1 & Erosion $(\mathrm{cm})$ & $20-30$ & $50-150$ & $10-20$ & $10-20$ & $5-10$ & $1-2 \mathrm{~cm}$ \\
2 & Solum (cm) & 0 & 0 & 0 & 0 & $20-30$ & $20-30$ \\
3 & Surface rock (\%) & $60-80$ & $60-80$ & $60-80$ & $60-80$ & - & - \\
\hline
\end{tabular}

Table 2. Water system analysis in Karai watershed.

\begin{tabular}{clccccccc}
\hline S.N. & Parameter (PP No 150 Th 2000) & GKE 1 & GKE 2 & GKE3 & GKE4 & GKE5 & GKE6 & GKE7 \\
\hline 1 & Available water (\%) & 46.78 & 3.35 & 14.61 & 18.74 & 29.28 & 30.62 & 46.77 \\
2 & Permeability (cm/jam) & 9.35 & 1.23 & 1.58 & 4.68 & 3.69 & 2.53 & 7.37 \\
3 & Infiltration (cm/jam) & 2.664 & 350 & 450 & 1.332 & 1.050 & 720 & 2.100 \\
\hline
\end{tabular}

Table 3. The change of water system due to converting natural forest to damaged land and gardening site.

\begin{tabular}{llllllll}
\hline S.N. & Parameter (PP No 150 Th 2000) & GKE 2 & GKE3 & GKE4 & GKE5 & GKE6 & GKE7 \\
\hline 1 & Available water (\%) & -43.43 & -32.17 & -28.04 & -17.50 & -16.16 & -0.01 \\
2 & Permeability (cm/hour) & -8.12 & -7.77 & -4.67 & -5.67 & -6.82 & -1.98 \\
3 & Infiltration (cm/hour) & -2.314 & -2.214 & -1.332 & -1.614 & -1.944 & -564 \\
\hline
\end{tabular}

Explanation : - (decrease); + (increase).

Table 4. Soil physical property analysis at Karai watershed.

\begin{tabular}{clccccccc}
\hline S.N. & Parameter & GKE 1 & GKE 2 & GKE3 & GKE4 & GKE5 & GKE6 & GKE7 \\
\hline 1 & Bulk density $\left(\mathrm{g} / \mathrm{cm}^{3}\right)$ & 0.64 & 1.73 & 1.40 & 1.54 & 1.34 & 0.97 & 0.78 \\
2 & Porosity (\%) & 75.95 & 34.88 & 47.05 & 41.77 & 49.50 & 63.46 & 70.74 \\
\hline
\end{tabular}

Tabel 5. Soil physical property changes due to converting natural forest to damaged land and gardening site.

\begin{tabular}{llllllll}
\hline S.N. & Parameter & GKE 2 & GKE3 & GKE4 & GKE5 & GKE6 & GKE7 \\
\hline 1 & Bulk density (gram/cm3) & +1.09 & +0.76 & +0.90 & +0.70 & +0.33 & +0.14 \\
2 & Porosity (\%) & -41.07 & -28.92 & -34.18 & -26.45 & -12.49 & -5.21 \\
\hline
\end{tabular}

- (decrease) ; + (increase). 
Damaging natural forest (tropical rain forest) to agricultural land has affected the rise of bulk density amounting to 0.14$1.09 \mathrm{~cm}^{2} / \mathrm{g}$. The rise of this bulk density is caused by land clearing using heavy equipment such as tractors, causing soil structure damage. On the other hand, the effect of compressing land will damage the pore of soil. This research result has proven that in this research site has soil pore damaged, which is land porosity decreases accounting for $5.21-41.07 \%$. This research result demonstrates that logging natural forest and land clearing with heavy equipment causes damage in soil physical property. this property is important to natural forest specificly for available water, permeability, porosity, drainage, and soil infiltration in which uncovered soil will causes the available water will run off on the soil and will eradicate soil structure increasing bulkl density. Soil structure damage will decrease soil porosity, permeability and soil infiltration. As a result soil damage to soil physical property will completely cause the decrease of hydrology function (water system) of Karai Watershed. This research is the same as the result of Hendrayanto et al. (2001) stating that surface run off of flood (water system decreases) could happened due to the decrease of soil infiltration capability and the lowered quality of covered land vegetation. It is also the same as the research of Aminudin (2012) stating that logging natural forest to cultivation line has caused the decrease of permeability accounting for $2.92 \mathrm{~cm} /$ hour, the decrease of porosity amounting to $2.93 \%$, the decrease of available water amounting to $3.22 \%$ and the increase of bulk density accounting for $0.08 \mathrm{~g} / \mathrm{cm}^{3}$.

Vegetation effects on eroded land show differently regarding the type of those plants, crown, growth level and climate. The effects of climate is probably close to the forest management and plants (Hardjowigeno, 2005; Rahim, 2006). The existence of good covering vegetation such as grass and thicked density forest could eradicate topography effects for erosion. Thightcovering vegetaion slows down run off and also prevents loss of soil particles. Type of vegetaion cultivated plays important role in preveting erosion (Arsyad, 2006). Rootage of plants tends to be closure of soil agregate and increase soil porosity. Root also could grab the soil mass for affecting shear strength value. Therefore, soil that has plant roots has high permeability. Different plants suprisingly has different characteristics in affecting soil. Plants that has big leaves will be easy to break down to vertile the soil, thus reducing the soil sensivity to erosion (Rahim, 2006). Overall erosion in thich natural forest will have low erosion levels called geology erosion (Arsyad, 2006; Wasis, 2012; Wasis et al., 2019). Forest conversion was carried out to land of rubber and palm oil farming with some actual agro technologies. Land of monoculture rubber I resulted the highest run off and soil erosion more than the other land use type and showeddifferent of run off and soil erosion on land of secondary forest (Sunarti et al., 2008).

\section{Soil chemical properties}

Laboatory analysis result illustrates that land clearing causes the damage of function of soil chemical property such as the decrease of $\mathrm{C}$ organic. The damage of soil chemical property will decrease the ability of soil in providing nutrition for the plants and decrease soil agregate stability (PP Number 150 2000). For futher detail, it is shown in Tables 6 and 7.

Demolishing forest and land causes the decrease of soil chemical analysis such as C Organic. The decrease of soil C organic accounting for $9.03 \%$ - 19.98\% (93\%). The biggest decrease of $\mathrm{C}$ organic occurs in open land, thus land coverage with vegetation is the most effective way to maintain soil fertility. Destroying natural forest has caused the loss of natural forest biomass. The loss of biomass tend to downgrade the ecosystem. In addition, destroying natura forest causes damage in soil chemical property such as the activities of logging and land clearing. Cutting trees in natural forest causes the loss of nutrition cycle in ecosystem. The loss of natural forest will affect the loss of branch, leaves, and nutrient. the decrease of organic materials on the forest ground will surely decrease the level of nutrients ( $\mathrm{N}, \mathrm{P}, \mathrm{Ca}, \mathrm{Mg}, \mathrm{K}$, and other soil materials). Those organic materials will decomposate into simpler compound. In addition, those organic materials will get into mineralisation process. Decomposated organic materials will assemble resistent organic compound for the next decomposition (humat compound) and part of that will be released as useful nutrients. Therefore, final decomposition process of those chemical materials could be (directly of indirectly) affected. For the importance of organic material functions, the decrease of organic material levels should be notified fastly (Tables 6 and 7).

Table 6. Soil chemical properties at Karai watershed.

\begin{tabular}{clccccccc}
\hline S.N. & Parameter (PP No 150 Th 2000) & GKE 1 & GKE 2 & GKE3 & GKE4 & GKE5 & GKE6 & GKE7 \\
\hline 1 & $\mathrm{pH}$ & 4.5 & 5.6 & 4.3 & 5.2 & 4.1 & 4.0 & 4.1 \\
2 & C-organic (\%) & 22.74 & 8.82 & 11.92 & 11.57 & 2.76 & 3.90 & 13.71 \\
\hline
\end{tabular}

Table 7. The change of soil chemical property due to natural forest convertion to damaged land and gardening site.

\begin{tabular}{clcccccc}
\hline S.N. & Parameter (PP No 150 Th 2000) & GKE 2 & GKE3 & GKE4 & GKE5 & GKE6 & GKE7 \\
\hline 1 & $\mathrm{pH}$ & +1.1 & -0.2 & +0.7 & -0.4 & -0.5 & -0.4 \\
2 & C Organic (\%) & -13.92 & -10.82 & -11.17 & -19.98 & -18.84 & -9.03 \\
\hline- - (decrease) ; + (increase). & & & & & &
\end{tabular}


Cultivating natural forest vegetation will cause the loss of biomass (log). In natural forest, log or biomass is the biggest component compared to other plant structures (such as branch and leaves). Consequently, natural forest cultivation indirectly tend to be the primary cause of the decrease of soil nutrients (Binkley, 1987; Evan, 2000I; Wasis, 2006; Aminudin, 2012). The damage of soil chemical property due to logging in natural forest will break nutrient cycle in the forest. The result of Indrawan's research (2003) shows that structures and composition of primary forest will decide the level of toughness of forest cultivation. It is predicted that the higher the density of comertial forest cultivation then the higher the damage is. The dectruction effects in cultivated forest site will affects a) the availibility of primary vegetation and their brood b) the availability of nutrients and c)other environment components such as temperature, humidity and other aspects. Reparation of soil chemical property could be done by giving them natural manure or green manure originated from Leuser Mountain Nation Park. The process of giving unorganic manure (chemical manure) is not recommended because it will cause polution. In addition, seed used for reboisation have to use endemic vegetation (Wasis and Noviani, 2010; Wasis and Fathia, 2011, Wasis, 2012).

\section{Soil biological properties}

Laboratory analysis result show that land clearing has caused the damage of soil biological function which has triggered the decrease of total microorganism, total fungi and respiration (PP Number 150 2000). For further detail, it is shown in the Tables 8 and 9.

Deforestation has degraded the total microorganism, total fungi, and respiration. In addition, the detail or total decrease of total microorganism $5.0 \times 10^{6} \mathrm{cpu}-11.0 \times 10^{6} \mathrm{cpu}$, the decrease of total fungi $1 \times 10^{4} \mathrm{spk}$ and soil respiration accounting for $12.16-23.08 \mathrm{mgC}-\mathrm{CO}_{2} / \mathrm{kg}$ soil/day. The result of this research has proven that converting natural forest to open land and gardening site causes the damage of soil biological property. Deforestation in Karai Warershed has caused the decrease of soil microorganism. The activity of deforestation should not be done because there are genetic sources and high diversities of microorganism The existence of microorganism fuctions as soil fertility maintanance. According to Subba Rao (1986), soil microorganism is needed to maintain soil fertality and could be the important factor for nutrient cycle. The restoration forest soi doul be made by giving inoculation VA-mikoriza and inculation Rhixobium to catalyze the growth (Rumondang and Setiadi, 2011; Tuheteru and Husna, 2011). Restoration of existed damaged land near Catchment Area could be done by giving compostite manure or other natural manure., inoculating microorganism (mikoriza) and replanting endemic vegetation (Wasis et al., 2018). According to Nguyen and Klinnert (2001), giving organic manure is recommended to maintain plant productivity and soil fertility. Giving organic manure into soil is the potential source of $\mathrm{N}, \mathrm{P}$, and $\mathrm{S}$ elements for vegetation growth (Evans, 2000). Decomposition of organic materials for microbiology is one of the most important steps to release nutrient bond to become simple form (Kumada, 1987). Giving inoculation mikoriza is needed to increase the growth rate of plants and to conservate nutrient.

\section{Vegetation analysis}

Convertion of natural forest converage into garden, road, and dwelling sites is found. The result of vegetation analysis using plot $(20 \mathrm{~m} \times 20 \mathrm{~m})$, at garden land closure and damaged soil is shown at Table 10.

Table 8. Soil biological properties analysis at Karai watershed.

\begin{tabular}{llccccccc}
\hline S.N. & Parameter (PP No 150 Th 2000) & GKE 1 & GKE 2 & GKE3 & GKE4 & GKE5 & GKE6 & GKE7 \\
\hline 1 & Total microorganism $\left(10^{6} \mathrm{cpu}\right)$ & 12.0 & 4.0 & 1.0 & 7.0 & 5.0 & 1.0 & 5.0 \\
2 & Total fungi $\left(10^{4} \mathrm{cpu}\right)$ & 1.0 & 0 & 0 & 0 & 0 & 0 & 1,0 \\
3 & Respiration $\left(\mathrm{mgC}-\mathrm{CO}_{2} / \mathrm{kg}\right.$ soil/day) & 26.68 & 3.60 & 5.88 & 9.72 & 5.84 & 6.28 & 14.52 \\
\hline
\end{tabular}

Table 9. The change of soil biological property due to converting natural forest to damaged land and gardening site.

\begin{tabular}{|c|c|c|c|c|c|c|c|}
\hline S.N. & Parameter (PP No 150 Th 2000) & GKE 2 & GKE3 & GKE4 & GKE5 & GKE6 & GKE7 \\
\hline 1 & Total microorganism $\left(10^{6} \mathrm{cpu}\right)$ & -8.0 & -11.0 & -5.0 & -7.0 & -11.0 & -7.0 \\
\hline 2 & Total fungi $\left(10^{4} \mathrm{cpu}\right)$ & -1.0 & -1.0 & -1.0 & -1.0 & -1.0 & 0 \\
\hline 3 & Respiration (mgC- $\mathrm{CO}_{2} / \mathrm{kg}$ soil/day) & -23.08 & -20.8 & -16.96 & -20.84 & -20.40 & -12.16 \\
\hline
\end{tabular}

- (decrease); + (increase).

Table 10. Result analysis of vegetation on plots $(20 \mathrm{~m} \times 20 \mathrm{~m})$ in natural forest and damaged soil at Karai watershed.

\begin{tabular}{clll}
\hline S.N. & Growth level/Potential level & Natural forest (GKE 1) & Damaged soil (GKE 2) \\
\hline 1 & Undergrowth & Types : 10 plants & - \\
2 & Seedlings & Types : 5 plants & - \\
3 & Saplings & Total : 6 plants; Volume $: 0.15 \mathrm{~m}^{3}$ & - \\
4 & Poles & Total : 3 plants; Volume $: 0.83 \mathrm{~m}^{3}$ & $-:$ Volume : $-\mathrm{m}^{3}$ \\
5 & Trees & Total : 10 Trees; Volume : $15.09 \mathrm{~m}^{3}$ & $-;$ Volume: $:-\mathrm{m}^{3}$ \\
& Total volume & Volume : $16.7 \mathrm{~m}^{3}\left(417.5 \mathrm{~m}^{3} / \mathrm{ha}^{2}\right.$ & ${\text { Volume }: 0 \mathrm{~m}^{3}}$ \\
\hline
\end{tabular}


Inside complete natural forest, there are vegetation statifications vertically (canopy/crown) and completely horizontally. Inside natural forest, there are also undergrowth plants, seedlings, saplings, poles and trees. Total volume of wellconserved natural forest is $417.5 \mathrm{~m}^{3} / \mathrm{ha}$. However, on the damaged soil there is no stratification of trees vertically and horizontally. On the other hand, on the cleared land there is no vegetation with total volume of $0 \mathrm{~m}^{3}$. Those observation results shows that on cleared land occured damaged vegetation of natural forest, which means the ability of land in absorbing carbon dioxide $\left(\mathrm{CO}_{2}\right)$ tend to decrease or dissapear. Besides that fact, soil become unprotected. Therefore, soil aggregate are eradicated triggering soil bulk density increases and run-off increases (Figures 5-7).

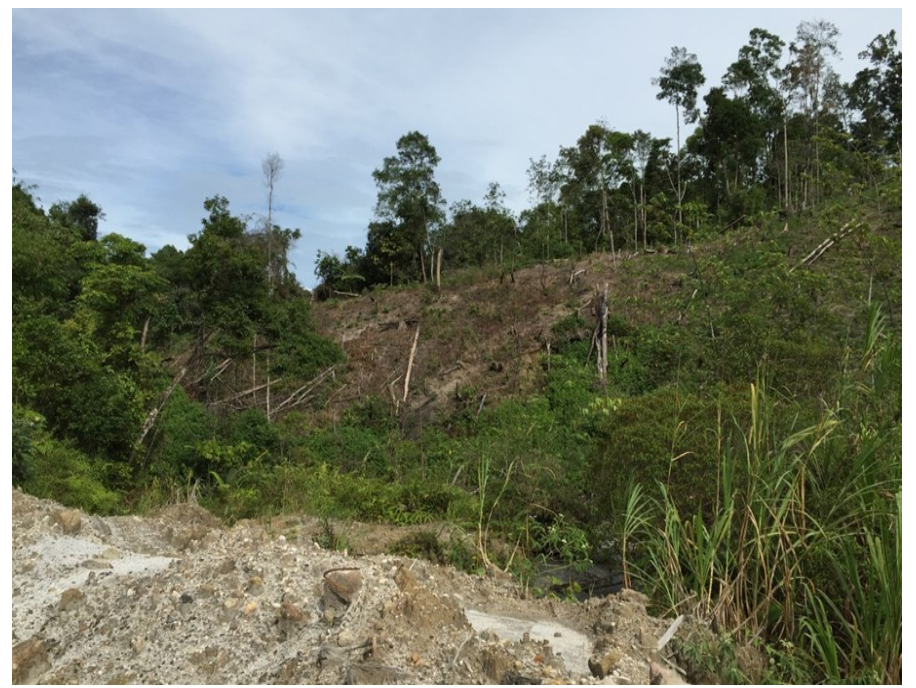

Figure 5. Natural forest areas encroached upon society at Karai watershed.

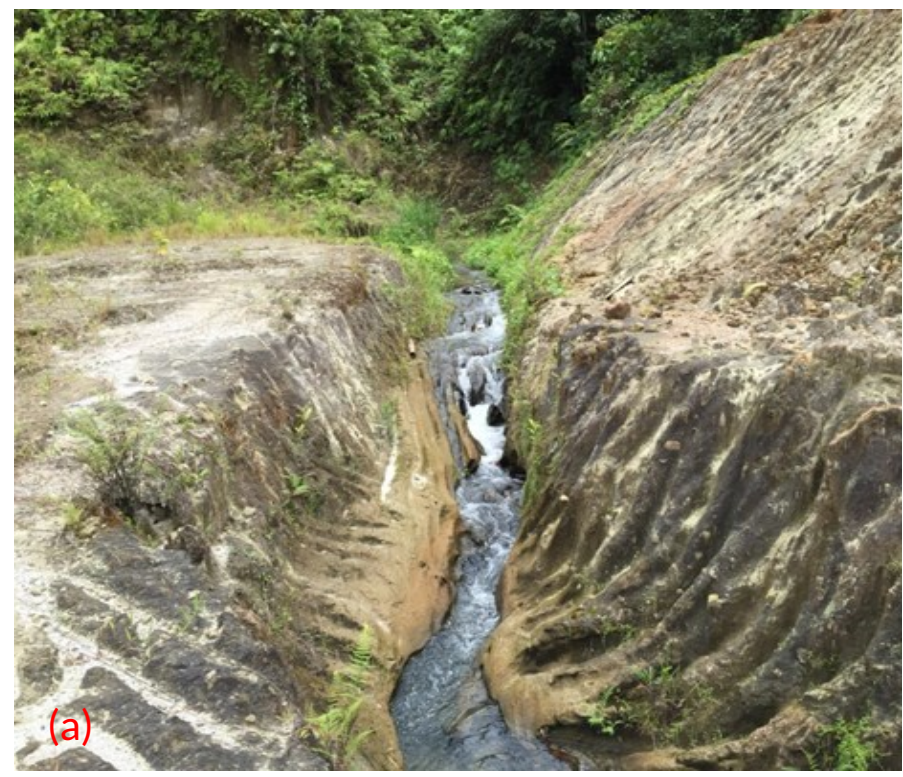

Type of endemic trees of natural forest in Karai catchment area: Shorea (Shorea sp.)

Cat Eyed Shorea (Shorea javanica)

Rengas (Glutha rengas)

Cengal(Hopea sangal)

Iron wood (Eusideroxylon zwageri)

Type of trees planted:

Sengon (Paraserianthes falcataria)

The type of undergrowth that is:

Palm (Cyrtostachysrenda)

Calliandra (Calliandra calothyrsus)

Bamboo (Bambusa sp.)

Rotan (Daemonorops sp.)

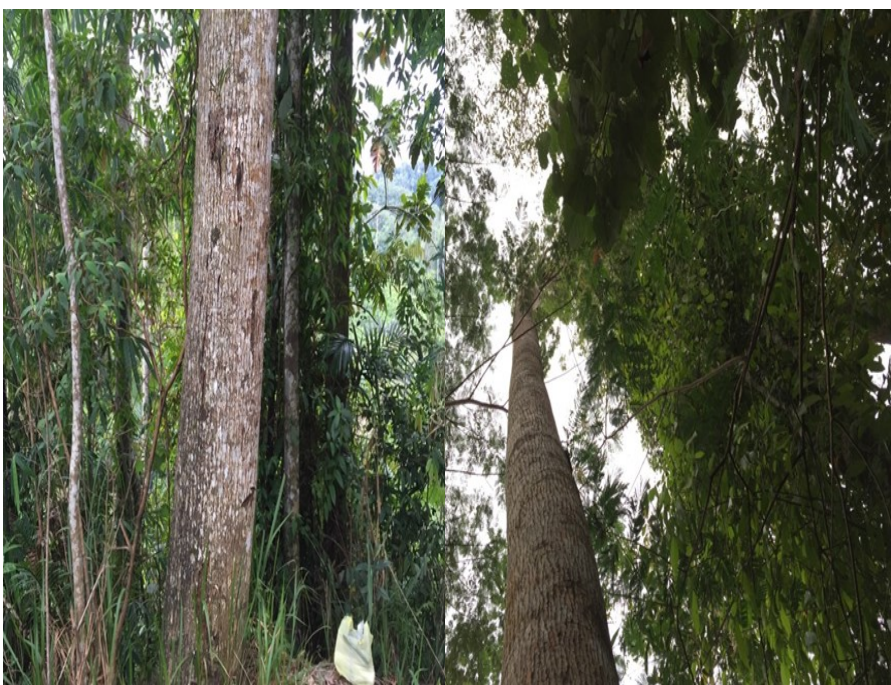

Figure 6. Natural forest (tropical rain forest) area in Karai watershed.

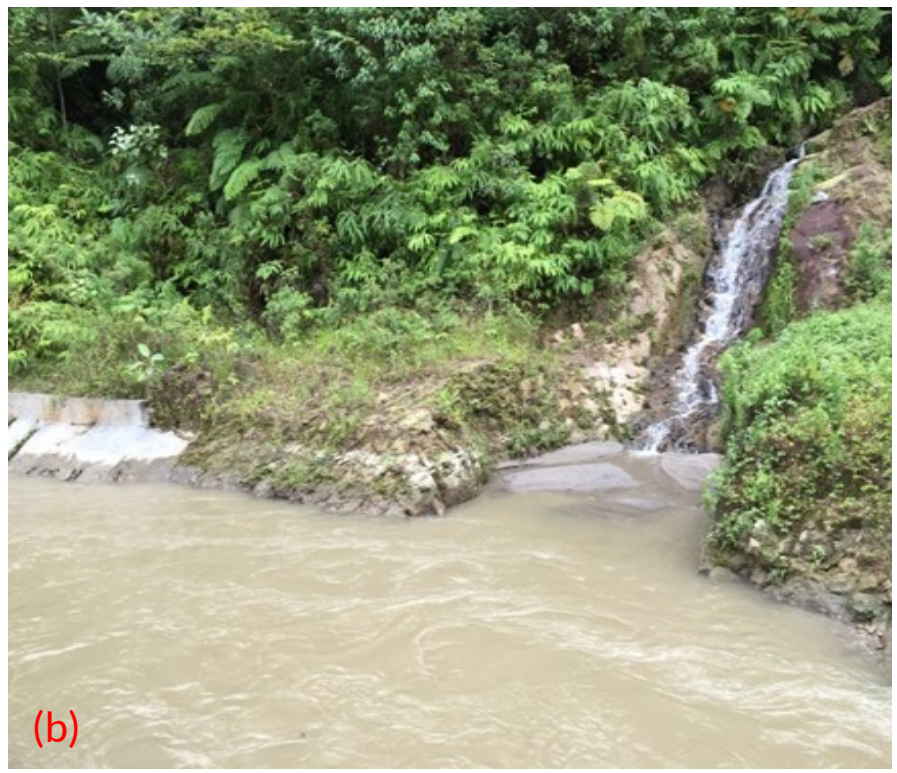

Figure 7. Comparison of water quality (a) water from natural forest, (b) water from Karai river 
Damaged soil and the lost of permanent vegetation (forest) is the reason why Karai Watershed area has low water quality and high dissolved sedimentaion. In the sedimentation process, the presence of forest land cover on a wide watershed is sufficient to reduce sediment flowing into the river (Junaidi and Tarigan, 2011).

According to observation and laboratory analysis could be disovered that damage on land and forest has occured in forest area, protertion area and non forest area. As a result to menage Karai catchment area ha to notice technical factors and social economic aspects for local citizen. Therefore, to solve the exist problems integrated catchment area management should be implemented. This research shows that the wider the natural forest cover, the lower surface runoff and erosion. Salim et al. (2019) stated that the simulation from several scenarios shows that a decreasing in forest area can increase discharge and surface runoff, whereas an increase in forest area will increase soil infiltration and evapotranspiration. Decreasing forest area by $10 \%$ from existing conditions caused $58 \%$ of rain water to become surface runoff. The large number of discrepancies between the existing conditions and the directions in the RTRWP will require a long time and large costs to adjust so that the short-term alternative that can be done is to convert dryland agricultural cover to the forest to reach forest cover of at least $45 \%$ of the land area in the upstream area and can optimize the hydrological function of the watershed.

\section{Integreted management of Karai watershed}

Karai Catchment area is one of the biggest catchment area in which located in Northern Sumatera Province. It has the wide of $462 \mathrm{~km}^{2}$ with non forest coverage amounting to $75 \%$. To answer the problem, integreted management of Karai catchment area is neccessary. To increase coordination and to continue communition processes among stakeholders to solve the problem, it needed to be insprative from those stakeholders. To make integrated program, activiteies and fundraising, it needs Integrated Management of Karai Watershed catalyzed participationly by including stakeholders (government, business community, academision and each individual). The reason is to achieve common mutual goals arranged together based on characteristic of natural capital such as upper are (atmosphere), soil and its component, vegetation, fauna, human capital including its intitutional (formal and informal), social capital and man made capital. With those plan in Karai Watershed, hopefully there are improvements among stakeholders in the resource management by coordinating, integrating and synchronizing policies with management and development of effective and efficient Watershed. Therefore, stakeholders construct programs and also do the activities for achieving common mutual arrangements.

Cases of land use changes in some areas in Indonesia will be presented with discussion on the causes and effects of watershed hydrology, especially in relation to carrying capacity and sensitivity of the watersheds and flood frequency. Hydrologic and discharge characteristics of some major rivers in Indonesia (especially in Java) will be given in relation to the status of watershed development. It was concluded that land use changes have occurred at large scale, especially in Java, and significant impacts on water yields of the river basins were observed, with increased frequencies of extreme events such as floods and droughts. Also of importance is the drop of present mean annual rainfall compared to earlier time of this century in Java and some other regions in Indonesia, which is believed to be related to the disappearance of proper forest land covers (Pawitan, 2014).

Logical framework for plannng integrated management of Karai watershed

Logical framework of this management should be built based on the results of meeting with other stakeholders. For further details, logical framework was illustrated in Table 11.

Table 11. Logical Framework for Karai watershed management.

\begin{tabular}{|c|c|c|}
\hline Goal & Objective & Output \\
\hline \multirow[t]{4}{*}{$\begin{array}{l}\text { Reducing contribution of Karai } \\
\text { Watershed for sedimentation, } \\
\text { flood, and increasing water } \\
\text { quality to fulfil the standard for } \\
\text { certain purposes. }\end{array}$} & \multirow[t]{2}{*}{$\begin{array}{l}\text { Increasing the } \\
\text { function of } \\
\text { absorbing area }\end{array}$} & $\begin{array}{l}\text { Improve the function of water absorption. } \\
\text { The wide of covered land increases. } \\
\text { Govenment: Protected land (Open green land, Protected land, } \\
\text { Conservation area, etc) including mixed forest, monoculture forest, } \\
\text { enriching resources in conservation area. } \\
\text { Local citizen: Owned land by local citizen is agroforestry, plants rotation } \\
\text { Company: Owned land for private sectors. } \\
\text { Adopted technology of soil and water conservation by stakeholders } \\
\text { increases. } \\
\text { Government: Control channel, dam checking, cross drainage on road and } \\
\text { crops area. } \\
\text { Citizen: Absorbing pit, crops area, cross drainage. } \\
\text { Company: Rorak, Cross drainage on road, rorak, dam checking, crops area } \\
\text { and free area to choose. }\end{array}$ \\
\hline & & Increasing water quality of Karai river \\
\hline & $\begin{array}{l}\text { Increasing water } \\
\text { quality }\end{array}$ & $\begin{array}{l}\text { Infrastructure disposal and waste management increases (government). } \\
\text { Management of household waste by citizen increases. }\end{array}$ \\
\hline & & Adopting environmentally friendly technology by industries increases. \\
\hline
\end{tabular}


Program recommendation for integrated management of Karai watershed

Based on logical framework that has been made with technical biophisics condition, managemen and social economy that has been implemented, stakeholders can arrange alternative activities tat could be done in each sub-district. Related to goals that has been approved to increase absorb function and water quality of the river, surface run off condition, sedimentation, and revenue level of citizen are factors to be considerated in deciding activities that should be done. The success of this program highly depends on citizens' support in local area. The support are measured by the level of revenue to land rehabilitation activities. Field observation result for land management could be recieved by citizen and environment do not destruct development soil in mixed gardening site and agroforestry. In addition, type of fruit cultivation period that has occured is banana, talas, rice, sweet, corn and ginger. On the other hand, cultivated trees in local communities are rubber, coffee, pinang, durian, bamboo, and kaliandra. According to observation results, it shows that Karai Watershead (75\%) is non forest area developed by local communities, thus the most effective alternatives to reduce run off and sedimentation is mixed-covered gardening site and agroforestry. Besides, the most important thing that PT Global Karai Energi should do to reduce run off and sedimentation in project locations (Karai 13 and Karai 7) are developing channls and rorak beside the road, developing terasiring in "cut and fill" road, replanting trees on uncovered soil, and replanting cover crop and making guludan (cross drainage). Research in the Karai watershed shows that forest cover will reduce erosion and sedimentation and improve water system and water quality. This is in line with the research of Romlah et al (2018) that the results showed that the change of forest cover in Way Seputih Hulu from 2000-2015 decreased $(26,32 \%$ to $11,26 \%)$ its function has been changed into settlement and plantations that affected the increasing of average discharge $\left(16,3 \mathrm{~m}^{3} / \mathrm{s}\right.$ to $\left.17,1 \mathrm{~m}^{3} / \mathrm{s}\right)$, maximum discharge $\left(32,7 \mathrm{~m}^{3} / \mathrm{s}\right.$ to $\left.49,8 \mathrm{~m}^{3} / \mathrm{s}\right)$, fluctuation of river discharge $(10,6$ to $49,8)$, runoff coefficient $(0,17$ to 0,23$)$ and the decreasing of minimum discharge $\left(3,1 \mathrm{~m}^{3} / \mathrm{s}\right.$ to $\left.\mathrm{m}^{3} / \mathrm{s}\right)$.

\section{Conclusion}

Land Cover for non forest area is the biggest sediment source in Karai Catchment Area. Based on observation on field and labolatory analysis, it shows that conservation activities in natural forest to garden, road, and dwelling site have caused damages to soil (parameter bulk density and total fungi) and environment with indicators of erosion, sediment materials in Karai River and Karai 7 Project location. Observation result shows that program to reduce erosion and sedimentation could be implemented by integrated management program of Karai Watershed with priorities to develop mixed garden and agroforestry.
Open Access: This is an open access article distributed under the terms of the Creative Commons Attribution 4.0 License, which permits unrestricted use, distribution, and reproduction in any medium, provided the original author(s) if the sources are credited.

\section{REFERENCES}

Aminudin, I. (2012). Perkembangan tegakan pada hutan alam produksi dalam Sistem gSilvikultur Tebang Pilih Tanam Indonesia Intensif (TPTI). [Disertasi] Bogor Sekolah Pascasarjana Institut Pertanian Bogor.

Arsyad, S. (2006). Konservasi Tanah dan Air. IPB Press. Bogor, Indonesia.

Bapenas (2003). Strategi dan Rencana Aksi Keanekaragaman Hayati Indonesia 2003-2020. IBSAP Dokumen Regional. Pemerintah Republik Indonesia.

Binkley, D. (1987). Forest nutrition management. Duke University, Durham, North Carolina. USA.

Evans, J. (2000). Sustainaibility of productivity in successive rotations. Proc. of International Conference on Timber Plantation Development. November 79, Manila, Phillipines.

Hardjowigeno, S. (2005). IImu Tanah. Akademika Pressindo. Jakarta

Hendrayanto, Arifjaya N.M., Rusdiana, O., Wasis, B. and Purwowidodo (2001). Respon hidrologi daerah aliran sungai (DAS) berhutan jati (Tectona grandis) Studi kasus di DAS Cijuray KPH Purwakarta Perum Perhutani Unit III Jawa Barat. Jurnal Manajemen Hutan Tropika, 7 (2) : 7-18.

Indrawan, A. (2003). Model sistem pengelolaan hutan alam setelah penebangan dengan Sistem Tebang Pilih Tanam Indonesia (TPTI). Jurnal Manajemen Hutan Tropika, 9 (2): 19-33.

Junaidi E. and Tarigan, S.D. (2011). Forest Influence in Water System Arrangement and Sedimentation Process on Watershed: Case Study in the Cisadane Watershed. Jurnal Penelitian Hutan dan Konservasi Alam, 8(2): 155-176.

Kumada, K. (1987). Chemistry of soil organic matter. Japan Scientific Societies Press. Tokyo.

Nguyen, T.D. and Klinnert, C. (2001). Problem with and local solution for organic matter management in Vietnam. Kluwer Academic Publishers, Printed in the Netherlands. Nutrient Cycling in Agroecosystems, 61: 89-91.

Nomor, P.P.R.I. (2000). Tahun 2000, tentang Kepelautan. Lembaran Negara Republik Indonesia Tahun.

Oldeman, L.R. (1992). The Global extent of soil degradation. Didalam : Greenland, DJ Szabole I Editor. Soil Resiliense and Sustainable Land Use. Procedings of a Symposium of Sustainable Land Use. Budapest : CAB International 99-105.

Pawitan, H. (2014). Land use changes and their impacts on watershed hydrology. See discussions, stats, and author profiles for this publication at: https:// www.researchgate.net/publication/237486643

Rahim, S.E. (2006). Pengendalian Erosi Tanah dalam Rangka Pelestarian Lingkungan Hidup. PT Bumi Aksara. Jakarta.

Romlah D.R., Yuwono S.B., Hilmanto, R. and Banuwa, I.S. (2018). The effect of forest cover changes on Way Seputih Hulu discharge. Jurnal Hutan Tropis, 6 (2): 197-204

Rumondang, J. and Setiadi, Y. (2011). Evaluasi aplikasi fungi mikoriza arbuskula (FMA) dan respon pertumbuhannya terhadap jati (Tectona grandis Linn. F) di persemaian Jurnal Silvikultur Tropika, 2 (3): 194-197.

Salim, A.G., Dharmawan, I. W. S. and Narendra, B.H. (2019). Pengaruh perubahan luas tutupan lahan hutan terhadap karakteristik hidrologi DAS Citarum Hulu. Jurnal Ilmu Lingkungan, 17(2): 333-340.

Soerianegara, I. and Indrawan, A. (2005). Indonesian orest Ecology. Department of Forest Management, Faculty of Forestry IPB, Bogor.

Subba Rao, N.S. (1986). Soil Microorganism and Plant Growth. Oxford and Publishing Co. New Delhi.

Sunarti., Sinukaban, N., Sanim, B. and Tarigan S. D. (2007). Konversi hutan menjadi lahan usahatani karet dan kelapa sawit serta pengaruhnya terhadap aliran permukaan dan erosi tanah di DAS Batang Pelepat. Jurnal Hutan Tropis, 13 (3): 253-260

Tuheteru, F.D. and Husna. (2011). Pertumbuhan dan biomassa Albizia saponaria yang diinokulasi fungi arbuskula mikoriza lokal Sulawesi Tenggara. Jurnal Silvikultur Tropika, 2 (3): 143-148. 
Wasis, B. (2006). Perbandingan kualitas tempat tumbuh antara daur pertama dengan daur kedua pada hutan tanaman Acacia mangium Willd. [Disertasi]. Bogor. Sekolah Pascasarjana Institut Pertanian Bogor.

Wasis, B. (2012). Soil properties in natural forest destruction and conversion to agricultural land in Gunung Leuser National Park, North Sumatera Province. Journal of Tropical Forest Management (JMHT), XVIII(3) : 206-212

Wasis, B. and Fathia, N. (2011). Pertumbuhan semai Gmelina dengan berbagai dosis pupuk kompos pada media tanah bekas tambang emas Jurnal Manajemen Hutan Tropika, 17(1): 29-33.

Wasis, B. and Noviani, D. (2010). Pengaruh pemberian pupuk NPK dan pertumbuhan Semai jabon (Anthocephalus cadamba Roxb Miq.) pada media tanah bekas tambang emas (tailing). Jurnal Ilmu Pertanian Indonesia, 15(1): 14-19.

Wasis, B., Arifin and Winata, B. (2018). Impact of bauxite mine to natural forest biomass and soil properties in Kas Island, Riau Island Province in Indonesia. Archives of Agriculture and Environmental Science, 3(3): 264-269.

Wasis, B., Saharjo, B.H., Putra, M.H.W. and Winata B. (2019). Analysis of environmental damage and environmental economic valuation on tropical rain forest destruction in Simalungun Regency, North Sumatera Province, Indonesia. Archives of Agriculture and Environmental Science, 4(3): 313-318.

Whitmore, T.C. (1975). Tropical Rain Forest of The Far East. Clarendom Press. Oxford. 